\title{
Seasonal and Milking-to-Milking Variations in Cow Milk Fat, Protein and Somatic Cell Counts
}

\author{
Elena RalucaPAVEL', Constantin GAVAN ${ }^{2}$ \\ ${ }^{1}$ University of Craiova, Faculty of Horticulture, 13 AI Cuza St., Craiova, Dolj, Romania; hellenas_ralu@yahoo.com \\ ${ }^{2}$ Agricultural Research Development Station, Simnic-Craiova, Balcești St., Dolj, Romania
}

\begin{abstract}
The first objective of this study was to examine milking-to-milking variations in milk fat, protein and SCC (somatic cell count). The second objective of this study was to examine variations of milk components (fat, protein and SCC) over a period of six months (April-September 2010) at Agricultural Research Development Station Simnic. A total of 128 milk samples (64 morning milking and 64 evening milking ones) from milk bulk tank commingled from $90 \pm 4$ Holstein cows, were collected and analyzed for fat, protein and SCC. Data suggested that milking period effects milk fat, making the fat percentage lower in the morning compared with the evening milking period, effect which was not similar in protein content. Seasonal differences in milk fat and protein were also investigated. The season of year had influenced SCC, fat and protein: SCC increased, while fat and protein decreased. The period of the day when milking took place and the season influenced fat, protein and SCC, but the composition of milk, as well as its hygienic quality, fell within the aplicabile standards for raw milk
\end{abstract}

Keywords: evening milking, fat, morning milking, protein, somatic cell count

\section{Introduction}

The main factors of milk chemical composition variation are well known and have long been the subject of experimental research. This variation is linked to cows (days in milk, breed, health, completeness of milking) or the environment (season and feeding). Among the environmental factors, nutrition plays a predominant role especially the amount of diet supplied and the nature of the ratio.

It has been reported that protein percentage has less day-to-day than milking-to-milking variation, with protein percentage 0.09 points higher in the evening (Quist et al., 2008). Fat percentage has more milking-to-milking variation than protein percentage, with fat percentage 0.32 points higher in the evening (Quist et al., 2008).

The significantly higher fat content at 6-h compared with the 12-h milking interval during the first half of the milking is probably related to the way oxytocin provokes active transport of high-fat alveolar milk. Thus, the highfat alveolar milk ejected at the end of the 12-h milking interval was not totally transferred along the mammary ducts before the milking ended (Lollivier et al., 2002). Therefore, when the cows were milked 6-h later, this high-fat alveolar milk was readily available in the foremilk, as well as at the beginning of the milking. Weiss et al. (2002) also reported higher milk fat levels with decreasing milking interval.

Somatic cells are mostly cells of the immune system ( $80 \%$ in uninfected quarters, $99 \%$ in mastitic quarters). These somatic cells are part of the natural defense mechanism and include lymphocytes, macrophages, polymor- phonuclear cells and some epithelial cells. Somatic cells are therefore a reflection of the inflammatory response to an intramammary infection or another trigger of the immune system. Somatic cell counts can indicate subclinical mastitis in herds or individuals. Infection status has the largest effect on SCC, even if the infection is on a short term. There is variation in SCC throughout milking, as well as diurnal variation from milking to milking. Diurnal variation consists of higher SCC in the evening than in the morning milkings, and the difference is assumed to be due to the interval between milkings.

The season affects milk component percentages and SCC, as Quist et al. (2008) also reported, as an inverse relationship between milk yield and component percentages, with summer milk production being higher, but percentages of fat and protein being reduced compared with the fall production and the one from winter months. $\mathrm{Ng}$ Kwai-Hang et al. (1984) concluded that milk and component yield variations were dependent on environmental conditions.

The common seasonal trend in SCC involves peaking in the late summer and decreasing to a low during the winter months (Gavan et al., 2009). Nevertheless, Ng-KwaiHang et al. (1984) found that SCC peaked during the winter months and was low in summer months, which was attributed to the cows being kept indoors in the winter and on pasture in the summer.

The main objective of this study was to describe the milking-to-milking variation of milk fat, protein percentages and SCC. Additional objectives were to investigate 
the seasonal factors that affect milk fat, protein content and SCC.

\section{Materials and methods}

The present study was conducted during April 2010 to September 2010 at Agricultural Research and Development Station Simnic Craiova (Romania). Somatic cell count was estimated using SOMASCOPE milk test MK II (Delta instruments). Fat and protein were determined using Ultrasonic Milk Analyzers ECOMILK (EON Trading). Assays were made on 128 composite milk samples collected in sterile bottles directily from the bulk milk tank. The milk samples were collected twice per day, after each milking.

Descriptive statistics-consisting of the mean, standard deviation, were derived for milk fat, protein and SCC. SCC were transformed to the logarithm for analysis, to avoid bias of the mean by extremely high raw SCC. The variability of fat and protein was calculated by substracting the lowest monthly average observed in the morning milking or evening milking from the highest monthly average.

\section{Results and discussion}

The milking period (morning vs. evening) considerable contributed to milk fat percentage variation.

Both mean fat and protein percentage peaked in the evening; however, fat increased from the morning milking to peak at the evening milking, whereas protein decreased from morning to evening. The mean fat content were spring morning $3.91 \pm 0.23$, spring evening $4.08 \pm 0.19$, summer morning $3.51 \pm 0.31$, summer evening $3.93 \pm 0.25$ and protein content was spring morning $3.41 \pm 0.05$, spring evening $3.45 \pm 0.14$, summer morning $3.16 \pm 0.11$, summer evening $3.25 \pm 0.1$. The protein percentage had less variability than the fat percentage from milking to milking as shown in Tab. 1 . The patterns of mean fat and protein percentage were consistent with those of Quist et al. (2008) and Verdi et al. (1987) who found that fat and protein percentages were higher in the evening milkings. Their results involved a herd milked also on a 12 hours interval. An increase in fat during the milking process has been reported in several studies (Lollivier $e t$ al., 2002) probably as a result of releasing the high fat milk which was not ejected at the morning milking.

$\mathrm{Ng}$-Kwai-Hang et al. (1984) found a difference of 0.65 for fat concentration between the morning milking and the evening milking and 0.26 respectively for protein content. Samples analysed in our study showed quite a small variability in milking-to-milking fat procentage, ranging from $0.06-0.42$. Milk protein proved less variable than the fat, with only 0.04-0.20 variation.

Milking-to-milking variation was not always consistent for milk fat, protein percentages and SCC. Milking period measurements can peak or drop drastically for various reasons, and if one test per day is performed at one of these milkings, the results of that test day can misinform the producer. Although in-line daily measurements of fat and protein are not currently available from milking equipment, as it is a technology that is foreseeable in the future.

Regarding the season, the mean fat content coming from evening milking peaked in June (4.16\%), but dropped to $3.66 \%$ in August, comparing with the morning milking which showed a constant decrease from 4.17 in April to 3.68 in September. Both fat and protein decreased slightly from 3.39 to 3.04 for fat, and 3.35 to 3.15 , respectively for protein. These results oppose with those of Agabriel et al. (1993), where fat and protein were low in winter, but they incresed after the return of the cows out to pasture. The steep rise in somatic cell counts in May is coincident with the cows being placed on pasture. Winters are long and cold, starting in November and continuing until late March. Internment of the cows in barns with approaching winter, confronts cows with new environmental stresses and bacterial challenges. Kennedy et al. (1982) noted that incidence mastitis is much higher during winter in areas where cows are indoors during the winter and on pasture in summer.

Spring grass or pasturing may have a specific transient and beneficial effect on milk protein. Seasonal increases in milk protein have being recorded for cows that were well fed during the winter (Agabriel et al., 1993). The chemical composition of milk can be highly variable in concentration, fat and protein, which can vary independetly, regardless of the factors that are difficult to control on the short term (calving period, type of feeding).

Average seasonal differences for fat and protein followed the expected seasonal trend with the highest value for fat $0.4 \%$ in spring and for protein $0.14 \%$ in summer (Tab. 2). It has been found in the present study that the content of protein is rather constant throughout the seasons. This agrees with other studies that have shown that protein composition is influence by feeding practices only to a small extend ( Schopen et al., 2009; Heck et al., 2009; Coulon et al., 1998; Ozrenk and Selcuk Inci, 2008).

In previous studies Lujerdean et al. (2007), Gavan et al. (2009) reported a lower fluctuation between the warm and the cold season for milk components.

The seasonal difference observed by Verdi et al. (1986) was $0.67 \%$ for fat and 0.3 to $0.5 \%$ for protein concentration.

Chandan et al. (2006) found an 10\% variation for both fat and protein in milk with lowest levels in summer (July and August) and the highest levels in autumn (October and November).

The mean fat and protein percentages were highest in morning and decreased in summer. In the evening, they continued to decline at a slower rate through spring and summer. The differences for fat from season to season were significant $(P<0.01)$, but were not significant $(P>0.05)$ in 
Tab. 1. Milking-to-milking variations in fat and protein content

\begin{tabular}{|c|c|c|c|c|c|c|c|c|c|c|c|c|}
\hline \multirow{2}{*}{$\begin{array}{l}\text { Month of } \\
\text { lactation }\end{array}$} & \multicolumn{2}{|c|}{$\begin{array}{c}\text { Morning } \\
\text { fat content }\end{array}$} & \multicolumn{2}{|c|}{$\begin{array}{c}\text { Evening } \\
\text { fat content }\end{array}$} & \multirow[t]{2}{*}{ Difference } & \multirow{2}{*}{$\begin{array}{c}\mathrm{p} \\
\text { value }\end{array}$} & \multicolumn{2}{|c|}{$\begin{array}{c}\text { Morning } \\
\text { protein content }\end{array}$} & \multicolumn{2}{|c|}{$\begin{array}{c}\text { Evening } \\
\text { protein content }\end{array}$} & \multirow[t]{2}{*}{ Difference } & \multirow{2}{*}{$\underset{\text { value }}{\mathrm{p}}$} \\
\hline & Mean\% & $\pm \mathrm{SD} \%$ & Mean\% & $\pm \mathrm{SD} \%$ & & & Mean\% & $\pm \mathrm{SD} \%$ & Mean $\%$ & \pm SD $\%$ & & \\
\hline April & 4.17 & \pm 1.02 & 4.11 & \pm 0.24 & +0.06 & $p>0.05$ & 3.39 & \pm 0.06 & 3.35 & \pm 0.03 & +0.04 & NS \\
\hline May & 3.71 & \pm 0.21 & 3.99 & \pm 0.24 & -0.28 & $\mathrm{p}<0.05$ & 3.46 & \pm 0.16 & 3.43 & \pm 0.15 & +0.03 & NS \\
\hline June & 3.87 & \pm 0.09 & 4.16 & \pm 0.18 & -0.03 & $\mathrm{p}<0.05$ & 3.37 & \pm 0.11 & 3.28 & \pm 0.18 & +0.09 & $\mathrm{p}<0.05$ \\
\hline Spring & 3.91 & 0.44 & 4.08 & \pm 0.22 & -0.17 & $\mathrm{p}<0.05$ & 3.40 & \pm 0.11 & 3.35 & \pm 0.12 & +0.05 & $\mathrm{p}<0.05$ \\
\hline July & 3.73 & \pm 0.64 & 4.15 & \pm 0.22 & -0.42 & $\mathrm{p}<0.01$ & 3.15 & \pm 0.39 & 3.35 & \pm 0.23 & -0.20 & $\mathrm{p}<0.01$ \\
\hline August & 3.12 & \pm 1.14 & 3.66 & \pm 0.91 & +0.54 & $\mathrm{p}<0.01$ & 3.04 & \pm 0.33 & 3.15 & \pm 0.24 & -0.11 & $\mathrm{p}<0.05$ \\
\hline September & 3.68 & \pm 0.21 & 4.00 & \pm 0.7 & -0.32 & $\mathrm{p}<0.05$ & 3.29 & \pm 0.21 & 3.25 & \pm 0.24 & +0.04 & NS \\
\hline Summer & 3.51 & 0.66 & 3.93 & \pm 0.61 & -0.42 & $\mathrm{p}<0.01$ & 3.16 & 0.31 & 3.21 & \pm 0.23 & -0.05 & $\mathrm{p}<0.05$ \\
\hline
\end{tabular}

Tab. 2. Seasonal variations of fat and protein content

\begin{tabular}{cccccccccccccc}
\hline & \multicolumn{4}{c}{ Spring } & \multicolumn{4}{c}{ Summer } & \multicolumn{3}{c}{ Difference fat } & Difference protein \\
\hline Morning & Fat $\%$ & \pm SD $\%$ & Protein $\%$ & \pm SD $\%$ & Fat $\%$ & \pm SD $\%$ & Protein $\%$ & $\pm S D \%$ & \pm & $\mathrm{p}$ value & \pm & $\mathrm{p}$ value \\
\hline & 3.91 & 0.44 & 3.40 & 0.11 & 3.51 & 0.66 & 3.16 & 0.31 & +0.4 & $\mathrm{p}<0.01$ & +0.11 & $\mathrm{p}<0.05$ \\
\hline Evening & 4.08 & 0.22 & 3.35 & 0.12 & 3.93 & 0.61 & 3.21 & 0.23 & +0.15 & $\mathrm{p}<0.05$ & +0.14 & $\mathrm{p}<0.05$ \\
\hline
\end{tabular}

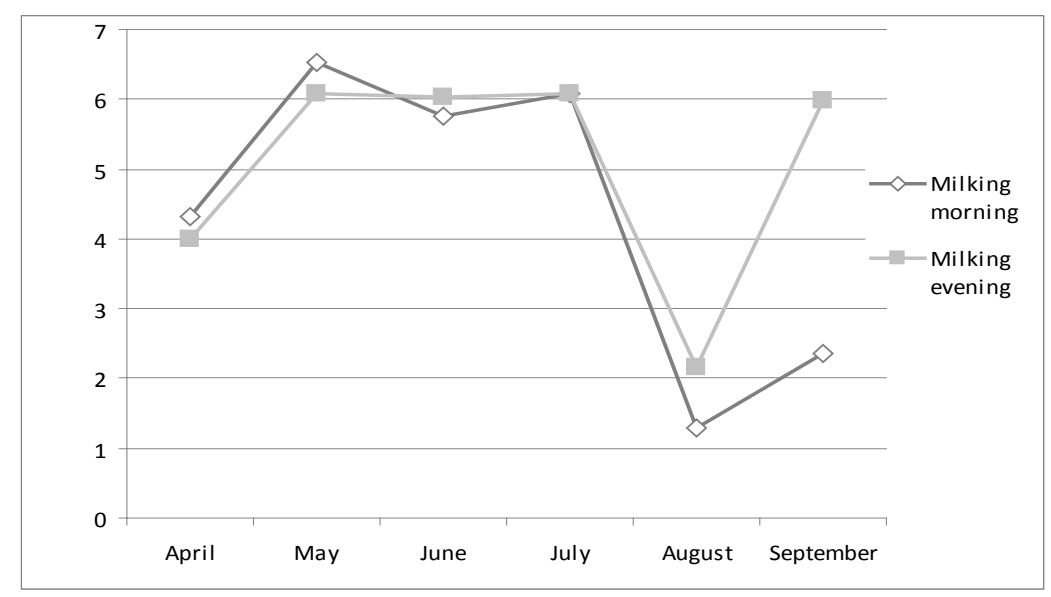

Fig. 1 . The number of somatic cells $(\times 100000 / \mathrm{ml})$ in raw milk

the evening. Protein differences were relatively small and accounted for only 0.11 to 0.14 of total variation.

There was a steady decline in fat and mean protein content count from spring to summer. The lowest fat and protein precentage are in summer morning for both characters.

The SCC results (Fig. 1) illustrate that throughout the studied period, no consistent milking-to-milking variations were present; however, evening milkings had the highest value each day.

A programme of monitoring udder health was introduce in September because of the high SCC registered in the morning (599 000 cells $/ \mathrm{ml})$. The animals with subclinical mastitis were isolated for treatment. Subclinical mastitis was diagnosised by using California Mastitis test. As a result, SCC from morning milking was only about half the value from the evening milking (235 000 cells/ $\mathrm{ml}$ comparing with 599000 cells $/ \mathrm{ml}$ ). A recent study with 15 milking samples collected consecutively over 3 day re- ported no consistent milking-to-milking variation and was always lower at the morning than the evening milking (Quist et al., 2008). Producers should not rely on a single test day SCC when managing mastitis.

Somatic cell counts are particularly useful to follow individual quarters or cows over a season. Only quarters and cows with long term high cell counts are indicators of a chronic infection and require further management attention. Short term high counts are not necessarily a reason for concern since an apparent immediate cure occurred.

It is unlikely that the pattern of somatic cell counts in this study was a chance occurrence, as the seasonal pattern has been repeated in subsequent years (Gavan et al., 2009). SCC demonstrated a seasonal trend, with higher SCC during the summer months than winter, data also observed by others authors. In Arizona, Nelson et al. (1967) found somatic cell counts highest from July to October and it began to decline after October. Bodoh et al. (1976) found seasonal patterns in Wisconsin inconsistent across 
years with a maximum in July in one year and sustained high cell counts from August through December in another year. In France (Kennedy et al., 1982), the highest somatic cell counts occurred between August and September, and in the Netherlands (Kennedy et al., 1982), the highest cell counts was in November although testing was not through the winter. In our study SCC dropped dramatically in August from a mean value of 608000 cells/ $\mathrm{ml}$ to 128000 , and respectively 235000 cells $/ \mathrm{ml}$. This change was obtained by monitoring subclinical mastitis using California Mastitis test.

\section{Conclusions}

Samples analysed in our study showed quite a small variability in milking-to-milking fat and protein content.

SCC fluctuation from milking-to-milking was not high, except for September evenings when SCC decline dramatically as a result of detecting animals with subclinical mastitis.

Further study is required to understand how season influence fat, protein and SCC, and the possibility to manipulate independently the mean concentrations of fat, protein and SCC.

Understanding the variability in milk fat, protein percentages and SCC is important when making management decisions and in milk-recording programs.

\section{References}

Agabriel C, Coulon JB, MartyG, Bonaiti B (1993). Changes in fat and protein concentrations in farms with high milk production. J Dairy Sci 76:734-741.

Bodoh GW, Battista WJ, Schultz LH, Johnston RP Jr (1976). Variation in somatic cell counts in Dairy Herd Improvement milk samples. J Dairy Sci 59:1119-1123.

Chandan R (2006). Manufacturing yogurt and fermented milks. Blackwell Publishing Iowa, USA.

Coulon, JB, Hurtaud C, Remond B, Verite R (1998). Factors contributing to variation in the proportion of casein in cow's milk true protein: A review of recent INRA experiments. J Dairy Res 65:375-387.

Heck JML, van Valenberg HJF, Dijkstra J, van Hooijdonk ACM (2009). Seasonal variation in the Dutch bovine raw milk composition. J Dairy Sci 92:4745-4755.
Gavan C, Patru C, Pavel ER, Ciobanu C (2009). Estimation of commercial milk quality parameters during season of the year in high producing Holstein cows. Annals of the University of Craiova XXXIX/A:132-136.

Lollivier V, Guinard-Flament J, Ollivier-Bousquet M, Marnet PG (2002 ). Oxytocin and milk removal: two important sources of variation in milk production and milk quality during and between milkings. Reproduction Nutrition Development 42:173-186.

Lujerdean A, Bunea A, Miresan V (2007). Seasonal related changes in the major nutrients of bovine milk (total protein, lactose, casein, total fat and dry matter). Scientific Papers University of Agricultural Science and Veterinary Medicine Iasi 52:372-374.

Kennedy BW, Sethar MS, Tong AKW, Moxley JE, Downey BR (1982). Environmental Factors Influencing Test-Day Somatic Cell Counts in Holsteins. J Dairy Sci 65:275-280.

Nelson FE, Schuh JD, Stott GH (1967). Influence of season on leucocytes in milk. J Dairy Sci 50:978.

Ng-Kwai-HangKF, MoxleyJE, Monardes HG (1984). Variability of Test-Day Milk production and composition and relation of somatic cell counts with yield and compositional changes of bovine milk. J Dairy Sci 67(2):361-366.

Ozrenk E, Selcuk Inci S (2008). The effect of seasonal variation on the composition of cow milk in Van Province. Pakistan Journal of Nutrition 7(1):161-164.

Quist MA, Blanc SJ, Hand KJ, Lazenby D, Miglior F, Kelton DF (2008). Milking to milking variability for milk yield, fat and protein percentage, and somatic cell count. J Dairy Sci 91(9):3412-3423.

Schopen GCB, Heck JML, Bovenhuis H, Visker MHPW, van Valenberg HJF, van Arendonk JAM (2009). Genetic parameters for major milk proteins in Dutch HolsteinFriesians. J Dairy Sci 92:1182-1191.

Verdi RJ, Barbano DM, Dellavalle ME, Senyk GF (1987). Variability in true protein, casein, nonprotein nitrogen, and proteolysis in high and low somatic cell milks. J Diary Sci $70(2): 230-242$.

Weiss D, Hilger M, Meyer HHD, Bruckmaier RM (2002): Variable milking intervals and milk composition. Milchwissenschaft 57:246-249. 